Check for updates

Cite this: RSC Adv., 2017, 7, 33812

Received 8th May 2017

Accepted 28th June 2017

DOI: $10.1039 / c 7 r a 05161 a$

rsc.li/rsc-advances

\title{
Rapid synthesis and properties of segmented block copolymers based on monodisperse aromatic poly( $N$-methyl benzamide) and poly(propylene oxide) $\uparrow$
}

\author{
T. Mori, ${ }^{a}$ S. Masukawa, ${ }^{a}$ T. Kikkawa, ${ }^{\text {b }}$ A. Fujimori, ${ }^{\text {b } A . ~ S a t o h, ~}{ }^{c}$ K. Matsumoto, ${ }^{c}$ M. Jikei, ${ }^{c}$ \\ Y. Oishi ${ }^{a}$ and Y. Shibasaki (D)*a
}

\begin{abstract}
Monodisperse aromatic $N$-methyl benzamide-based molecules (repeat number: $x=5-10$, molar mass distribution $\left.M_{w} / M_{n}=1.02-1.04\right)$ connected with terephthalic acid at both sides $\left(M A B_{x-x}\right)$ were rapidly prepared by a step-wise condensation reaction using the reported one-pot dendrimer synthetic method. These were copolymerized with $\mathrm{NH}_{2}$-terminated poly(propylene oxide) $\left(\mathrm{PPO}_{y}\right)$ using a condensation reagent at ambient temperature, and the relationship between the structure and the properties was

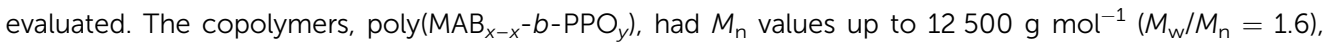
with only a single $T_{\mathrm{g}}$ at $-70{ }^{\circ} \mathrm{C}$ by DSC, assignable to the pure PPO domain. Only for the copolymer films consisting of a monodisperse $M A B_{x-x}$ segment, did the dynamic mechanical analysis (DMA) show two $T_{\mathrm{g}}$ values at -70 and above $50{ }^{\circ} \mathrm{C}$, indicating the clear phase segregation of the copolymers. The mechanical properties of the copolymer films were mostly dependent on the fraction of the monodisperse hard segment, and the tensile modulus and elongation at break varied from 3.3 to $32.5 \mathrm{MPa}$ and 150 to $540 \%$, respectively.
\end{abstract}

\section{Introduction}

A material prepared of a block copolymer having hard and soft segments (HSs and SSs) in the same chain shows unique properties due to the immiscible polymer segments, and is thus applicable in various fields such as membranes, ${ }^{1-7}$ photonics, ${ }^{8-12}$ lithography, ${ }^{12-16}$ nanocarriers, ${ }^{17,18}$ and thermoplastic elastomers (TPEs). ${ }^{19}$ TPEs are currently receiving much attention since they are recyclable and do not require additional chemical crosslinking reactions. The hard domains are strongly governed by physical packing, rather than chemical crosslinking, and are melted or softened at high temperatures. TPEs exhibit elastomeric properties that are comparable to those of chemically cross-linked rubbers, and like conventional thermoplastics, show good processability. Poly(ether- $b$-amide) multiblock copolymers (PEBA) are a class of important TPE materials due to the tuneable properties with variable polyether SSs and the highly

${ }^{a}$ Department of Chemistry \& Biological Sciences, Faculty of Science \& Engineering, Iwate University, 4-3-5 Ueda, Morioka, Iwate 020-8551, Japan. E-mail: yshibasa@ iwate-u.ac.jp

${ }^{b}$ Graduate School of Science and Engineering, Saitama University, 255 Shimo-okubo, Sakura-ku, Saitama 338-8570, Japan

'Department of Applied Chemistry, Akita University, 1-1, Tegatagakuen-machi, Akitashi, Akita 010-8502, Japan

$\dagger$ Electronic supplementary information (ESI) available. See DOI: $10.1039 / \mathrm{c} 7 \mathrm{ra05161a}$ thermostable aliphatic amide segment that realizes the reliable mechanical strength even at high temperatures. ${ }^{20-25}$ One of the most important application of PEBA can be the gas separation membrane, ${ }^{26-31}$ in which the crystalline amide HS increases the separation selectivity while the soft poly(ether) segment functions as high gas permeability. The properties of TPE materials are, of course, dependent on the types, length, and the molar mass dispersity of the individual segments. However, in generally speaking, polymers like PEBA are prepared via condensation polymerization, and thus, the lengths of the HSs are not well aligned (broad molar-mass distribution $\left(M_{\mathrm{w}} / M_{\mathrm{n}}\right)$ of around 2). On the condensation polymers, Harrell first prepared well-defined non-hydrogen-bonding segmented poly(urethane)s via step-wise reactions. ${ }^{32}$ The mechanical properties of these polymers were strongly affected by the length and size distribution of the HSs not by SSs. He also found that an HS with one repeat unit only cocrystallized with those containing two repeat units and not with those containing more repeat units. Samuels and Wilkes studied poly(urethane)s using WAXS, where an increasing HS length resulted in higher crystallinity with a thicker lamellar structure. $^{33}$ Hydrogen-bondable segmented poly(urethane)s based on 4,4'-methylenebis(phenyl isocyanate) (MDI), poly (tetramethylene oxide) (PTMO), and butanediol were then reported by Miller and his co-workers, and found that the polymers having a low $M_{\mathrm{w}} / M_{\mathrm{n}}$ in the HSs showed a smaller degree of phase mixing, and thus, higher strain in the polymers. ${ }^{34}$ Despite the 
controllable toughness and the elongation ability by choosing an isocyanate molecule as a proper HS unit, the flow temperature of these polymers is typically from 50 to $150{ }^{\circ} \mathrm{C}$, and they tend to degrade on heating over the melting temperature. Therefore, thermally more stable amide groups can be favored, especially for the high temperature TPE usage. As a novel type PEBA, Gaymans and Van Hutten reported a series of hydrogen-bondable segmented copolymers based on a monodisperse aliphatic- and aromatic-mixed bis(ester amide) as a HS unit. For example, a HS composed of two terephthaloyl with one 1,4-butylene diamino centre, called (T4T) was copolymerized with aliphatic diols. The $\mathrm{T} 4 \mathrm{~T}$ units (4 indicates the $\mathrm{C}$ number in aliphtatic chain) crystallized very fast and almost completely, resulting in a low diamide concentration in the polyether phase. ${ }^{35}$ The uniform $\mathrm{T} 4 \mathrm{~T}$ segments formed perfect and stable crystalline lamellae, resulting in a temperature-independent rubbery plateau. They also prepared monodisperse aliphatic- and aromatic-mixed diamide HSs such as T2T, ${ }^{36}$ T6T,${ }^{37}$ and oligoamide HSs of T6T6T and T6T6T6T. ${ }^{38}$ The tuneable $T_{\mathrm{m}}$ from 111 to $225^{\circ} \mathrm{C}$ with the monodisperse HS structure be useful as high-performance TPE materials, and also the materials were applied to gas separation membrane with the excellent $\mathrm{CO}_{2}$ permeability. ${ }^{39}$ Despite such many useful properties, the synthesis of the hydrogenbondable HSs with uniform length requires multi-step tedious procedures, which may constrict the industrial application.

Aromatic polyamides, such as poly(p-phenylene terephthalamide) (Kevlar) and poly(benzamide), have attracted extensive attention due to their inherently extended rigid-rod structure, which is caused by the para-linked benzene rings with the double bond character of the trans-amide linkage. ${ }^{40-42} \mathrm{~A}$ structural study based on X-ray crystallography, with conformational energy calculations of hydrogen-bondable terephthalamide model compounds, was performed by Flory and his coworker. ${ }^{43}$ On the other hands, nonhydrogen-bondable $N$ methylbenzamide was prepared, and the stereo chemistry of the amide bond structure was determined to be cis by X-ray analysis, whereas that of benzanilide was trans. ${ }^{44-47}$ They also prepared a 1,2-bis( $N$-benzoyl- $N$-methylamino)benzene molecule, from which optically active crystals were obtained. The amide linkage was again cis, but the molecule had $C 2$ symmetry. ${ }^{48}$ Therefore, the circular dichroic spectra of the crystal solutions show positive and negative Cotton effects. Yokozawa and his co-workers prepared non hydrogen-bondable aromatic poly(benzamide) bearing a chiral side chain via condensative chain polymerization (thus, the $M_{\mathrm{w}} / M_{\mathrm{n}}$ was around 1.1) and investigated the structure in solution and in the solid state, where the polymer had a unique one-handed helical structure depending on the chirality. ${ }^{49}$ We have prepared a series of non hydrogen-bondable poly( $N$-alkyl benzamide)s [ $\mathrm{PABA}_{n}(n$ indicates the $\mathrm{C}$ number of $\mathrm{C}_{n} \mathrm{H}_{2 n+1}$ at the side group)] by conventional direct condensation polymerization of $p$-( $N$-alkylamino)benzoic acids and elucidated the structures and packing of the $\mathrm{PABA}_{n}$ polymers using IR spectroscopy, elemental analysis, DSC, WAXD, and SAXS. The prepared $\mathrm{PABA}_{1}$ and $\mathrm{PABA}_{n}$ (where $n=2-5$ ) samples were insoluble in all organic solvents, and the tight packing was assignable to a monoclinic and orthorhombic structure between the main-chain dipolar interaction of the cis amide function. In contrast, while $\mathrm{PABA}_{17}$ also possessed crystalline structures, it crystalized in hexagonal lattices through weak van der Waals interactions of the alkyl side chains. ${ }^{50}$ Various higher-ordered layered structures of $\mathrm{PABA}_{n}$ were also manufactured by the Langmuir Blodgett method, and the color of the interference structure was observed from the differences in the layer thickness of the stepwise multiparticle layers. ${ }^{51-53}$ For the synthesis of aromatic polyamide dendrimers, we have demonstrated a simple and highly efficient convergent approach without protection and deprotection steps, using thionyl chloride. ${ }^{54}$ Therefore, utilizing this reliable step-wise technique, we expected that aromatic $\mathrm{PABA}_{n}$ molecules with a "perfectly" defined molecular weight can be rapidly prepared and applied to the synthesis of a novel type aromatic-based-PEBA with poly(propylene oxide) (PPO). The nonhydrogen-bondable monodisperse aromatic amide HS would show higher thermostability compared to the aliphatic-based-PEBA material. Moreover, the use of $\mathrm{N}$-methylated aromatic amide HS with a cis configuration would show higher solubility, so that the design and the synthesis of the HS with the desired length be easily attainable. Here, we demonstrate the synthesis and properties of a block copolymer based on oligo(4- $N$-methyl benzamide) (crystalline molecule) having an almost uniform length with PPO (typical amorphous polymer), using the facile dendrimer synthetic approach.

\section{Results and discussion}

\section{Synthesis of aramid molecules}

We performed a step-by-step reaction to construct the rigid-rod aramid molecules; the two carboxylic acids at the terminals of the compound were activated in situ with thionyl chloride, followed by condensation with the building block, 4-(methylamino)benzoic acid (MAB), according to the procedure for our previously reported dendrimer synthetic method, ${ }^{54}$ as shown in Scheme 1.

The highly pure targeted aramid compounds with the desired number of repeating units $\left(\mathrm{MAB}_{x-x}\right.$, where $x=5,6,7,8$, 9 , and 10$)$ were readily obtained in good yields $(77-83 \%)$. The aramid molecules are crystalline compounds, and thus, were recrystallized with methanol/water mixed solvent, giving pale brown fine powders. Fig. 1 depicts the ${ }^{1} \mathrm{H}$ NMR spectra of the $\mathrm{MAB}_{x-x}$ molecules. Along with the protons of the main chain, $a_{-}$ $d$, the protons at the terminal units, $c(t)$, were observed at $7.85 \mathrm{ppm}$ to have reasonable integration values, which supported the successful formation of the highly pure targeted HS, $\mathrm{MAB}_{x-x}$ molecule. The ${ }^{1} \mathrm{H}$ NMR spectra also showed that the prepared molecules had cis geometry at the amide function. ${ }^{44}$

The $N$-methylated aramide molecules were then subjected to the GPC analysis. Fig. 2 depicts typical $\mathrm{MAB}_{x-x}$ molecules prepared (a) by the step-wise and (b) by the conventional polycondensation methods using terephthalic acid in one-step reaction in NMP. The former $\mathrm{MAB}_{5-5}$ molecule shows the reasonable $M_{\mathrm{n}}$ of $1071 \mathrm{~g} \mathrm{~mol}^{-1}$ (theoretically $1500 \mathrm{~g} \mathrm{~mol}^{-1}$ ) along with the quite narrow $M_{\mathrm{w}} / M_{\mathrm{n}}$ value of 1.03. In contrast, the conventional one-step polycondensation polymer $\left(b \mathrm{MAB}_{5-5}\right)$ shows the $M_{\mathrm{n}}$ of $1470 \mathrm{~g} \mathrm{~mol}^{-1}$ with the $M_{\mathrm{w}} / M_{\mathrm{n}}$ of 1.45 . However, 

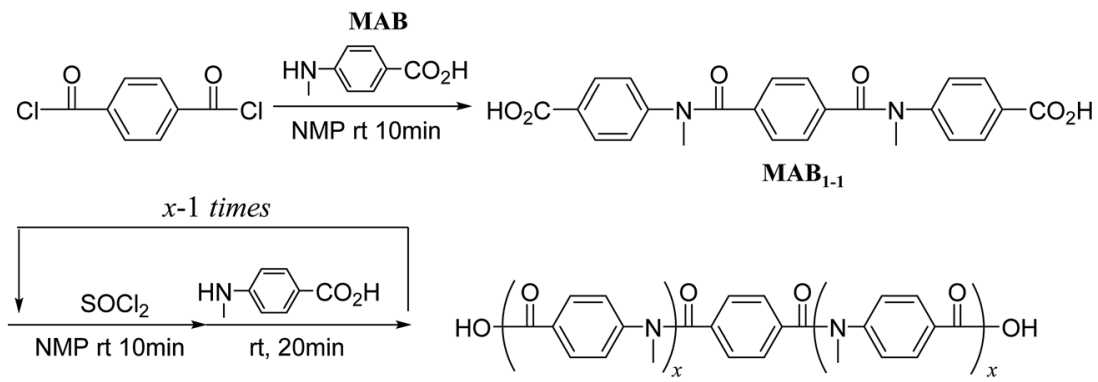

MAB $_{x-x}$

$(x=5,6,7,8,9,10)$

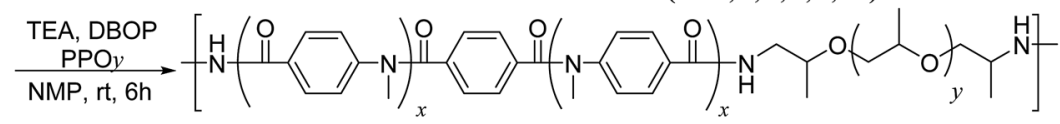

$\operatorname{Poly}\left(\mathbf{M A B}_{x-x}-b-\mathbf{P P O}_{y}\right)$

$(y=30,67)$

Scheme 1 Synthesis of the $N$-methyl poly(p-benzamide)s $\left(M^{\prime} B_{x-x}\right)$ and the block copolymerization with $\mathrm{PPO}_{y}$.

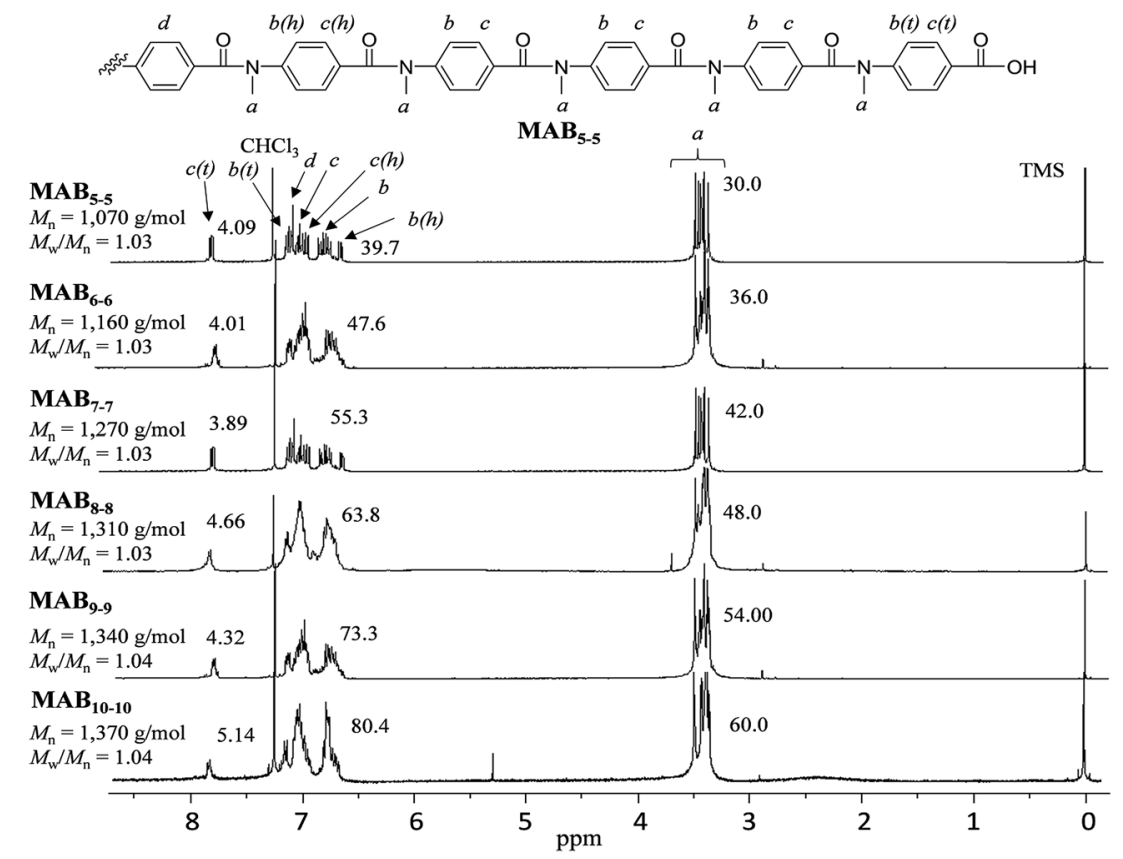

Fig. $1{ }^{1} \mathrm{H}$ NMR spectra $\left(\mathrm{CDCl}_{3}\right)$ of the $N$-methyl poly(p-benzamide)s $\left(\mathrm{MAB}_{x-x}\right)$ and the molecular-weight data by GPC.

the MALDI-TOF mass spectrum of the monodisperse $\mathrm{MAB}_{5-5}$ molecule shows that the molecule is not a single one, but still the mixture of $\mathrm{MAB}_{x-x}$ compounds as shown in Fig. 3. Although the $\mathrm{MAB}_{5-5}$ by the step-wise reaction has some molar-mass distribution, we thought that this still can be useful for the copolymerization with PPO to elucidate the phase segregation and the mechanical properties under the effect of the molarmass distribution.

To investigate the thermal behaviour, we then performed a DSC experiment. Fig. 4 depicts the DSC profiles of $\mathrm{MAB}_{x-x}$ molecules prepared via step-wise process. In a previous paper, we reported that $\mathrm{PABA}_{n}(n=1-5)$ were all crystalline polymers, whose crystal structures were well assigned by WAXD experiments. However, the melting temperature $\left(T_{\mathrm{m}}\right)$ of $\operatorname{poly}(N$ methyl benzamide) (poly(MAB)) was too high to measure with DSC, and only $T_{\mathrm{g}}$ was observed at $200{ }^{\circ} \mathrm{C} .{ }^{35}$ The $\mathrm{MAB}_{x-x}$ molecules prepared in this study showed a clear thermal transition at around $170-178{ }^{\circ} \mathrm{C}$, and thus, can be assigned as the $T_{\mathrm{g}}$ of the molecules. As expected, these values increased with the length of the $\mathrm{MAB}_{x-x}$ molecules.

\section{Synthesis of block copolymers of $\mathrm{MAB}_{\boldsymbol{x}-\boldsymbol{x}}$ with $\mathrm{PPO}_{\boldsymbol{y}}$}

As described in Introduction, the mechanical properties of TPEs were primarily affected by the length and size distribution of the HSs, not of the SSs. Therefore, we then copolymerized 


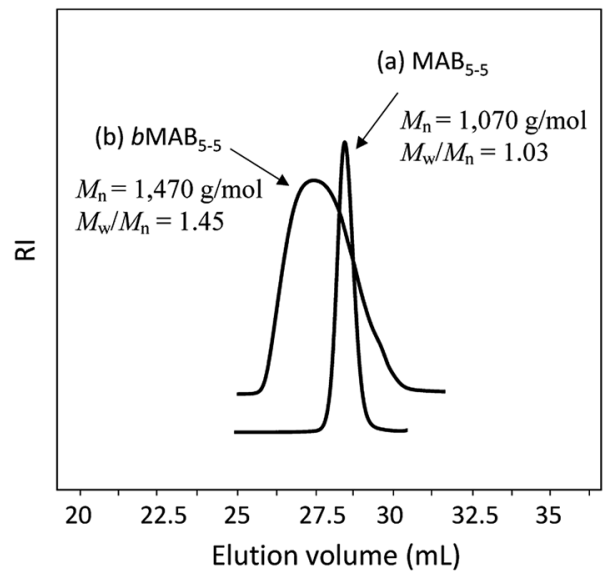

Fig. 2 GPC profiles of (a) $M A B_{5-5}\left(M_{n}=1070 \mathrm{~g} \mathrm{~mol}^{-1}, M_{w} / M_{n}=1.03\right)$ and (b) $b M^{\prime} B_{5-5}\left(M_{\mathrm{n}}=1470 \mathrm{~g} \mathrm{~mol}^{-1}, M_{\mathrm{w}} / M_{\mathrm{n}}=1.45\right)$.

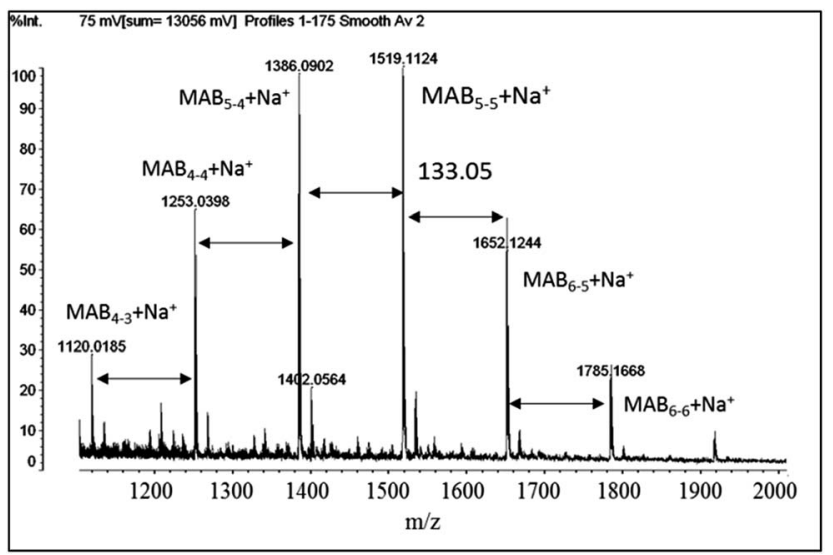

Fig. 3 MALDI-TOF MS spectrum of $\operatorname{MAB}_{5-5}\left(M_{\mathrm{n}}=1110 \mathrm{~g} \mathrm{~mol}^{-1}, M_{\mathrm{w}} /\right.$ $\left.M_{\mathrm{n}}=1.03\right)$.

monodisperse $\mathrm{MAB}_{x-x}$ with commercially available $\mathrm{PPO}_{y}$, whose $M_{\mathrm{w}} / M_{\mathrm{n}}$ was not well controlled, as shown in Scheme 1 . The resultant mixture was poured into water to precipitate the polymer. The viscous pale brown coloured polymer was washed with hot water several times to remove low-molecular-weight impurities.

Fig. 5 shows the GPC profiles of (a) $\mathrm{PPO}_{30}$ and the block copolymer (b) poly $\left(\mathrm{MAB}_{5-5}-b-\mathrm{PPO}_{30}\right)$. The unimodal peak of $\mathrm{PPO}_{30}$ was completely shifted into the higher-molecular-weight region, with a reasonable $M_{\mathrm{w}} / M_{\mathrm{n}}$ of 1.79 as a condensation polymer. Fig. 6 depicts the ${ }^{1} \mathrm{H}$ NMR spectra of (a) $\mathrm{MAB}_{5-5}$, (b) $\mathrm{PPO}_{30}$, and (c) poly $\left(\mathrm{MAB}_{5-5}-b-\mathrm{PPO}_{30}\right)$ in $\mathrm{CDCl}_{3}$. In the spectrum of the finally obtained polymer, the signals assignable to $\mathrm{MAB}_{5-}$ ${ }_{5}$ segments $a^{\prime}, b^{\prime}, c^{\prime}$, and $d^{\prime}$ were observed at 3.35-3.72 and 6.75$7.21 \mathrm{ppm}$ in addition to the signals assignable to $\mathrm{PPO}_{30}$ segments $f^{\prime}, g^{\prime}$, and $h^{\prime}$ at $3.45-3.75,3.45-3.20$, and $0.93-$ $1.20 \mathrm{ppm}$, respectively. The signal $e^{\prime}$ corresponding to the twoterminal $\mathrm{CH}_{3}$ protons of $\mathrm{PPO}_{30}$ was originally observed at $1.01 \mathrm{ppm}$, and this was shifted to $1.30 \mathrm{ppm}$ after the formation of the amide bond from the amine functions. The integrations

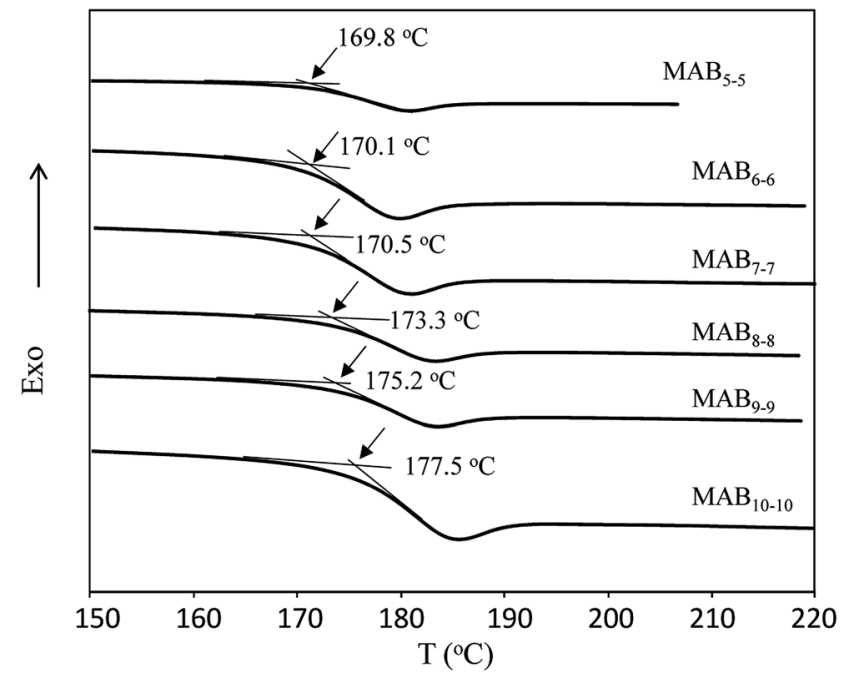

Fig. 4 DSC profiles of $\mathrm{MAB}_{x-x}$ samples (heating rate $20^{\circ} \mathrm{C} \mathrm{min}-1, \mathrm{~N}_{2}$ ).

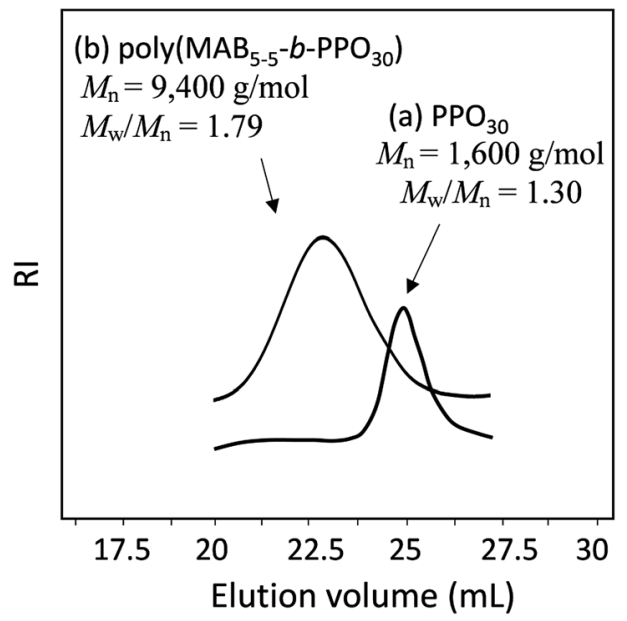

Fig. 5 GPC profiles of (a) $\mathrm{PPO}_{30}\left(M_{\mathrm{n}}=1600 \mathrm{~g} \mathrm{~mol}^{-1}, M_{\mathrm{w}} / M_{\mathrm{n}}=1.30\right)$ and (b) poly $\left(\mathrm{MAB}_{5-5}-b-\mathrm{PPO}_{30}\right)\left(M_{\mathrm{n}}=9400 \mathrm{~g} \mathrm{~mol}^{-1}, M_{\mathrm{w}} / M_{\mathrm{n}}=1.79\right)$.

of the terminal $e^{\prime}$ protons should not change to be 6.00 , and in this case, the integration at around 3.5 ppm became 124.6, in which about 91.6 integration values could be assigned to $\mathrm{PPO}_{30}$ segment $f, g^{\prime}$, and $h^{\prime}$ protons, so the 124.6-91.6 $=33.0$ integration is assignable to the $\mathrm{CH}_{3}$ protons of the $\mathrm{MAB}_{5-5}$ segment. From these calculations, we can estimate the compositions of $\mathrm{MAB}_{5-5}$ and $\mathrm{PPO}_{30}$ in the copolymer to be $1.1: 1.0$, which is in good agreement with the feed of the molecules $(1.0: 1.0)$. Along with the GPC results, it was obvious that the copolymer, poly($\mathrm{MAB}_{5-5}-b-\mathrm{PPO}_{30}$ ), was satisfactorily formed with the expected structure by this process.

Table 1 summarizes the results of the copolymerization. All polymers were obtained in good yield with $M_{\mathrm{n}}$ values of up to $12500 \mathrm{~g} \mathrm{~mol}^{-1}$. The morphology of the resulting polymers ranged from viscous sticky materials to hard solids, depending on the weight fraction $\left(f_{\mathrm{HS}}\right)$ of the aramid molecules. The resulting polymers showed excellent solubility to typical 


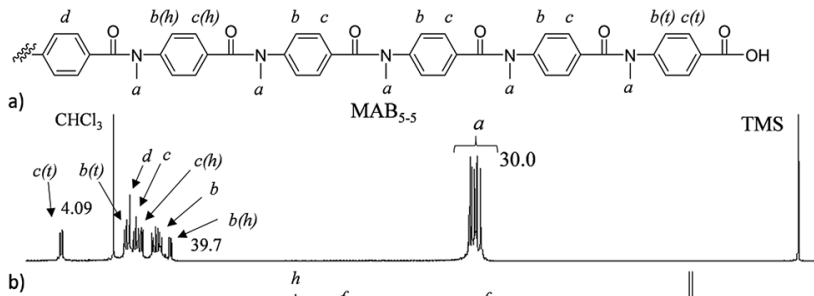

b)

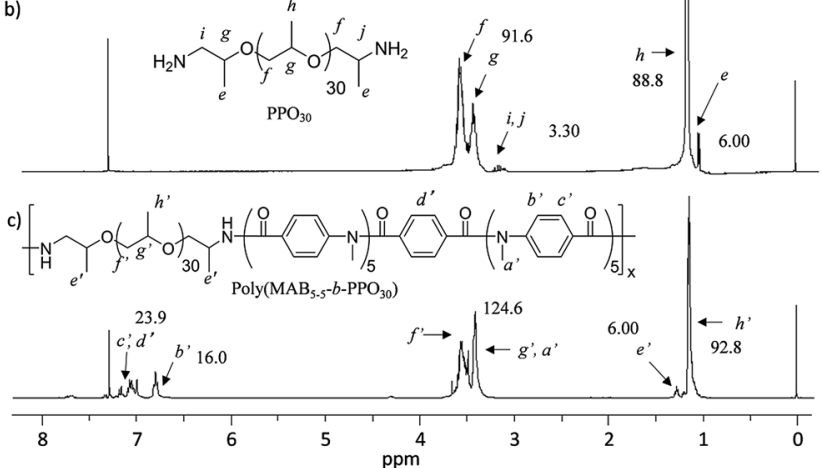

Fig. $6{ }^{1} \mathrm{H}$ NMR spectra $\left(\mathrm{CDCl}_{3}\right)$ of (a) $\mathrm{MAB}_{5-5}$, (b) $\mathrm{PPO}_{30}$, and (c) pol$y\left(\mathrm{MAB}_{5-5}-b-\mathrm{PPO}_{30}\right)$.

Table 1 Synthesis of copolymers poly $\left(\mathrm{MAB}_{x-x}-b-\mathrm{PPO}_{y}\right)^{a}$

\begin{tabular}{llllll}
\hline Run & $x / y$ & Yield $(\%)$ & $M_{\mathrm{n}}{ }^{b}\left(\mathrm{~g} \mathrm{~mol}^{-1}\right)$ & $M_{\mathrm{w}} / M_{\mathrm{n}}{ }^{b}$ & $f_{\mathrm{HS}}{ }^{c}(\%)$ \\
\hline $1^{d}$ & $5 / 30$ & 85.1 & 8400 & 1.4 & 44.8 \\
$2^{e}$ & $5 / 30$ & 84.3 & 8800 & 1.5 & 44.8 \\
3 & $5 / 30$ & 84.2 & 9400 & 1.8 & 44.8 \\
4 & $6 / 30$ & 88.8 & 9100 & 2.1 & 48.8 \\
5 & $6 / 67$ & 83.2 & 11600 & 2.0 & 30.7 \\
6 & $7 / 30$ & 80.6 & 9400 & 1.8 & 52.2 \\
7 & $7 / 67$ & 86.0 & 11000 & 1.8 & 33.8 \\
8 & $8 / 30$ & 70.4 & 8800 & 2.3 & 55.3 \\
9 & $8 / 67$ & 65.6 & 9000 & 2.2 & 36.5 \\
10 & $9 / 30$ & 77.0 & 10000 & 2.3 & 57.9 \\
11 & $9 / 67$ & 73.1 & 9800 & 2.3 & 39.1 \\
12 & $10 / 30$ & 74.0 & 11000 & 1.6 & 60.3 \\
13 & $10 / 67$ & 76.0 & 12500 & 1.6 & 41.5
\end{tabular}

${ }^{a}$ Conditions; DBOP 1.2 equiv. in $2 \mathrm{~mL}$ NMP at $20{ }^{\circ} \mathrm{C}$ for $6 \mathrm{~h}$.

${ }^{b}$ Determined by GPC (NMP containing $0.01 \mathrm{M} \mathrm{LiBr}$, PSt standards).

${ }^{c}$ Weight fraction of HS. ${ }^{d}$ DBOP 1.0 equiv. ${ }^{e}$ DBOP 1.1 equiv.

common organic solvents including methanol, acetone, chloroform, tetrahydrofuran, and polar aprotic solvent, $\mathrm{N}, \mathrm{N}$-dimethylformamide. Fig. 7 depicts the DSC profiles of the copolymers. All polymers have a clear thermal transition at $-70{ }^{\circ} \mathrm{C}$, assignable to the PPO segments, but no other transitions were observed over the temperature range measured.

\section{Properties of block copolymers $\left[\operatorname{poly}\left(\mathrm{MAB}_{x-x}-b-\mathrm{PPO}_{y}\right)\right]$ and the influence of $M_{\mathbf{w}} / M_{\mathrm{n}}$}

Fig. 8 depicts the DMA and the tan $\delta$ curves of poly( $\mathrm{MAB}_{5-5}-b$ $\left.\mathrm{PPO}_{67}\right)\left(M_{\mathrm{n}}=8800 \mathrm{~g} \mathrm{~mol}^{-1}, M_{\mathrm{w}} / M_{\mathrm{n}}=2.2\right)$ and poly $\left(b \mathrm{MAB}_{5-5}-b\right.$ $\left.\mathrm{PPO}_{67}\right)\left(M_{\mathrm{n}}=9400 \mathrm{~g} \mathrm{~mol}^{-1}, M_{\mathrm{w}} / M_{\mathrm{n}}=1.8\right)$ prepared with monodisperse $\left(M_{\mathrm{w}} / M_{\mathrm{n}}=1.03\right)$ and polydisperse $\left(M_{\mathrm{w}} / M_{\mathrm{n}}=1.45\right)$ $\mathrm{MAB}_{5-5}$ molecules as HSs, respectively. Even though these finally obtained polymers have similar $M_{\mathrm{n}}$ and $M_{\mathrm{w}} / M_{\mathrm{n}}$ values,

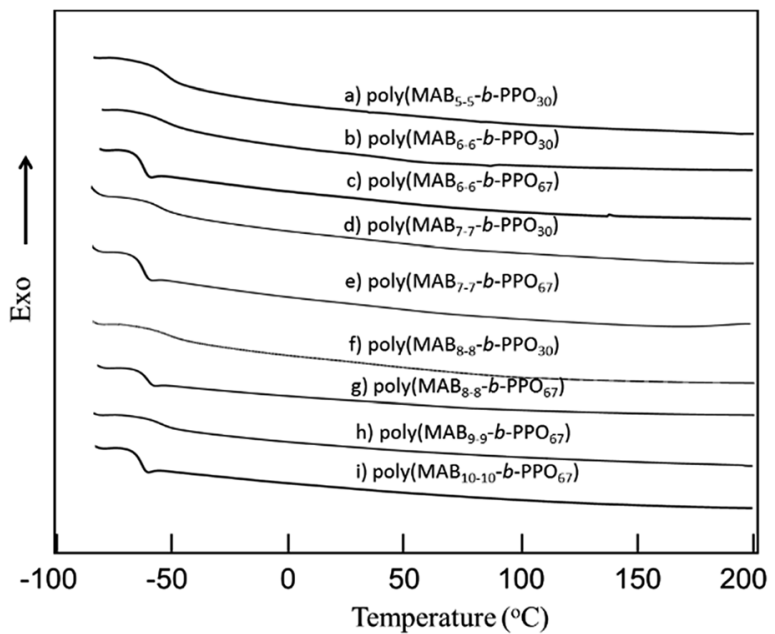

Fig. 7 DSC profiles (second scan) of (a) poly $\left(\mathrm{MAB}_{5-5}-b-\mathrm{PPO}_{30}\right)$, (b) poly $\left(\mathrm{MAB}_{6-6}-b-\mathrm{PPO}_{30}\right)$, (c) poly $\left(\mathrm{MAB}_{6-6}-b-\mathrm{PPO}_{67}\right)$, (d) poly $\left(\mathrm{MAB}_{7-7^{-}}\right.$ $\left.b-\mathrm{PPO}_{30}\right)$, (e) poly $\left(\mathrm{MAB}_{7-7}-b-\mathrm{PPO}_{67}\right)$, (f) poly $\left(\mathrm{MAB}_{8-8}-b-\mathrm{PPO}_{30}\right)$, (g) poly $\left(\mathrm{MAB}_{8-8}-b-\mathrm{PPO}_{67}\right)$, (h) poly $\left(\mathrm{MAB}_{9-9}-b-\mathrm{PPO}_{67}\right)$, and (i) poly($\left.M A B_{10}-10^{-b}-\mathrm{PPO}_{67}\right)\left(20^{\circ} \mathrm{C} \mathrm{min}^{-1}, \mathrm{~N}_{2}\right)$.
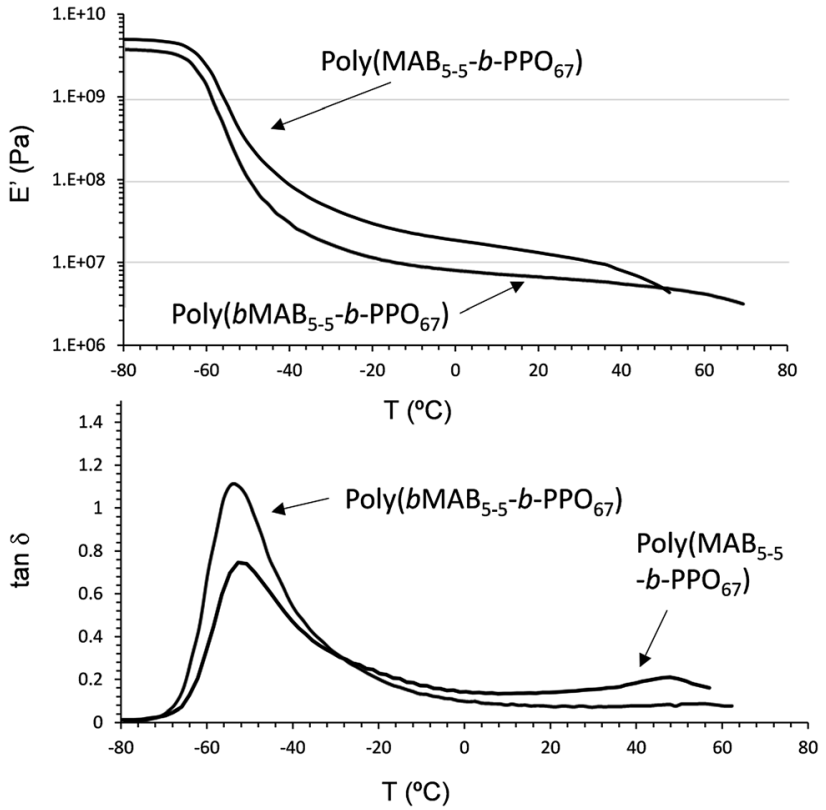

Fig. 8 DMA analysis of poly $\left(\mathrm{MAB}_{5-5}-b-\mathrm{PPO}_{67}\right)$ having monodisperse $\mathrm{HS}\left(M_{w} / M_{n}=1.03\right)$ and poly $\left(b M A_{5-5}-b-\mathrm{PPO}_{67}\right)$ having polydisperse HS $\left(M_{\mathrm{w}} / M_{\mathrm{n}}=1.45\right)$ ( $E^{\prime}$ vs. Temp and tan $\delta$ vs. Temp plots).

the initial storage modulus $E^{\prime} 4.84 \mathrm{GPa}$ of poly $\left(\mathrm{MAB}_{5-5}-b-\mathrm{PPO}_{67}\right)$ consisting of monodisperse $\mathrm{HS}$ was higher than that of poly($\left.b \mathrm{MAB}_{5-5}-b-\mathrm{PPO}_{67}\right)$ film $\left(E^{\prime}=4.15 \mathrm{GPa}\right)$. The peak intensity of $\tan \delta$ at $-50.7^{\circ} \mathrm{C}$ of poly $\left(\mathrm{MAB}_{5-5}-b-\mathrm{PPO}_{67}\right)$ consisting of monodisperse HS was obviously lower than the other sample, and also it has two distinct peaks at -50.7 and $47.9{ }^{\circ} \mathrm{C}$ in $\tan \delta$, which indicated the existence of more clear phase segregation of the HS block in the copolymer. Indeed, the appearance of poly $\left(\mathrm{MAB}_{5-5}-b-\mathrm{PPO}_{67}\right)$ consisting of monodisperse HS film was 


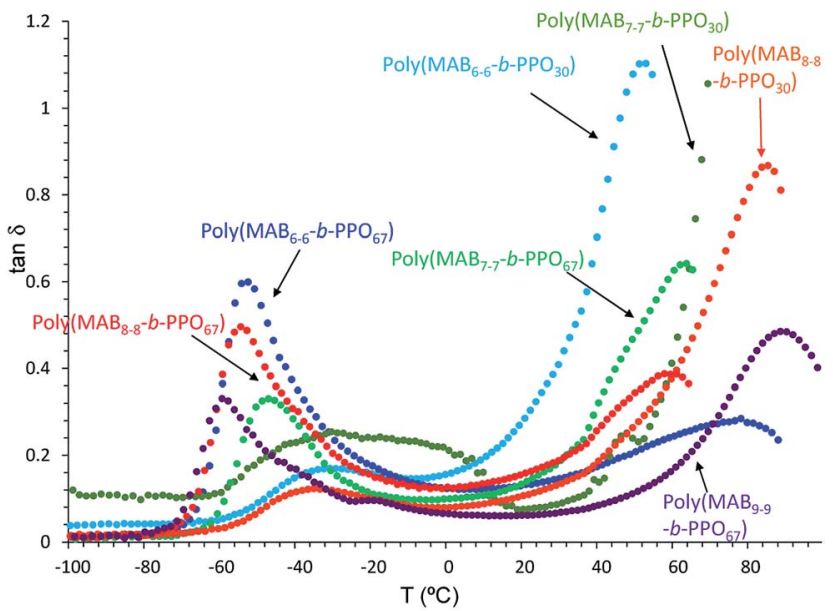

Fig. 9 Relationship between $\tan \delta$ and Temp obtained by DMA analysis of poly $\left(\mathrm{MAB}_{x-x}-b-\mathrm{PPO}_{y}\right)$ block copolymers.

opaque and tough, while that of the other one $\left[\mathrm{poly}\left(b \mathrm{MAB}_{5-5}-b-\right.\right.$ $\left.\mathrm{PPO}_{67}\right)$ film] was transparent and soft. These results indicated that in order to make the clear phase-segregated structure in the polymer film consisting of non-hydrogen-bondable $N$-methylated aromatic poly( $p$-benzamide), the use of the monodisperse HS block is essential.

Fig. 9 depicts the relationship between $\tan \delta$ and the measured temperature of the copolymer films. In contrast to the weak intensity of $\tan \delta$ peak observed in Fig. 8, more clear peaks were observed above $50{ }^{\circ} \mathrm{C}$ for the poly $\left(\mathrm{MAB}_{x-x}-b-\mathrm{PPO}_{y}\right)(x \geq 6)$ samples. For example, poly $\left(\mathrm{MAB}_{6-6}-b-\mathrm{PPO}_{30}\right)$ shows a small and large peak at -30.5 and $53.0{ }^{\circ} \mathrm{C}$, respectively, suggesting the stronger effect of the HS molecules. However, as seen in the DMA curve (Fig. S3†), there is no plateau region. For the polymer having a longer $\mathrm{HS}$, poly $\left(\mathrm{MAB}_{8-8}-b-\mathrm{PPO}_{30}\right)$, the $\tan \delta$ peak was shifted into higher region. For the polymers having a longer SS, such as poly $\left(\mathrm{MAB}_{6-6}-b-\mathrm{PPO}_{67}\right)$, poly $\left(\mathrm{MAB}_{7-7}-b-\mathrm{PPO}_{67}\right)$, poly($\left.\mathrm{MAB}_{8-8}-b-\mathrm{PPO}_{67}\right)$, and poly $\left(\mathrm{MAB}_{9-9}-b-\mathrm{PPO}_{67}\right)$, all showed a clearer drop in $E^{\prime}$ at a lower temperature of $-60{ }^{\circ} \mathrm{C}$. In particular, for a poly $\left(\mathrm{MAB}_{9-9}-b-\mathrm{PPO}_{67}\right)$ film, the $\tan \delta$ peak intensity at -57.7 and $90.3{ }^{\circ} \mathrm{C}$ became similar. In the DMA curve, $E^{\prime}$ started to decrease at around $-71.2^{\circ} \mathrm{C}$ and the second drop was observed at from $68.1^{\circ} \mathrm{C}$ having clear plateau region between them.

From the data obtained above, we can conclude that the phase-separation conditions of the films are as follows. (A) For the polymers having a short SS, there can be a phase-separated region consisting of SSs significantly contaminated with HSs and HSs containing some quantities of SSs. (B) For the polymers having long SSs with long HSs, the two phases can be separated, and the phase separation should be better for longer HS samples.

To investigate the polymer microstructures in the films, we then performed a WAXD experiment (Fig. 10). In our previous study, we prepared poly(MAB) via conventional polycondensation of MAB with a small amount of terephthalic acid, and the crystal structure was assigned to be monoclinic with

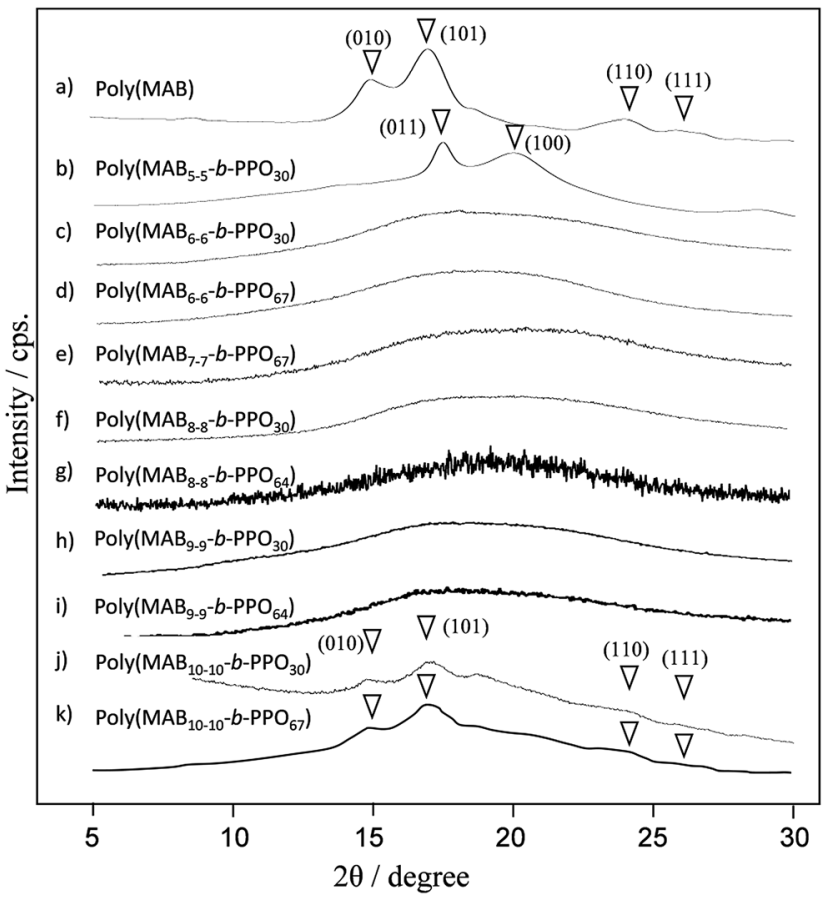

Fig. 10 Powder WAXD profiles of (a) the MAB homopolymer poly($\left.M A B_{x-y}\right)$, and (b)-(k) poly $\left(M^{\prime} B_{x-x}-b-P P O_{y}\right)$.

parameters $a=7.7 \AA, b=5.7 \AA, c=7.9 \AA, \alpha=\gamma=90^{\circ}$, and $\beta=$ $67.5^{\circ}$. The WAXD profile of the polymer powder of poly $\left(\mathrm{MAB}_{5-5^{-}}\right.$ $\left.b-\mathrm{PPO}_{30}\right)$ is depicted in Fig. 10(b), from which the crystal structure was assigned as triclinic with parameters $a=4.6 \AA$, $b=6.5 \AA, c=7.9 \AA, \alpha=86^{\circ}, \beta=67.5^{\circ}$, and $\gamma=100^{\circ}$. Note that the crystallized $\mathrm{MAB}_{5-5}$ from a methanol/water mixed solvent did not show a clear diffraction pattern in the WAXD experiment. Thus, we assumed that the HSs cannot align well alone. However, they are placed in a regular manner in the solid-state block copolymer, where the PPO segment $\left(T_{g}=-68^{\circ} \mathrm{C}\right)$ acted as the solvent even at ambient temperature. In contrast, for the poly $\left(\mathrm{MAB}_{x-x}-b-\mathrm{PPO}_{y}\right)$, whose $x$ values range from 6 to 9 , all samples showed only amorphous hollows in the profiles. However, the packing was recovered for the poly $\left(\mathrm{MAB}_{10-10^{-}}-b\right.$ $\mathrm{PPO}_{y}$ ) sample, returning to the crystal structure to be original monoclinic lattice. This can be explained by the polymers having relatively short HSs being unable to crystalize into the stable monoclinic lattice because of the inadequate length of the HSs.

In order to evaluate the phase segregated structure in more detail, we measured AFM of the poly $\left(\mathrm{MAB}_{5-5}-b-\mathrm{PPO}_{67}\right)$, poly($\mathrm{MAB}_{9-9}-b-\mathrm{PPO}_{67}$ ) films (Fig. S11†). Unfortunately, not very clear phase-separation was observed in the images. The former sample seems the rough surface with large phase separation in topography, and the other one shows more precise separation. In the prepared films, the phase separation mainly occurred within the films, and was not appeared on the film surface. Since the interaction between the HS units in our system (nonhydrogen bondable) is rather weak compared with those of hydrogen-bondable PEBA, the existence of the longer HS must 


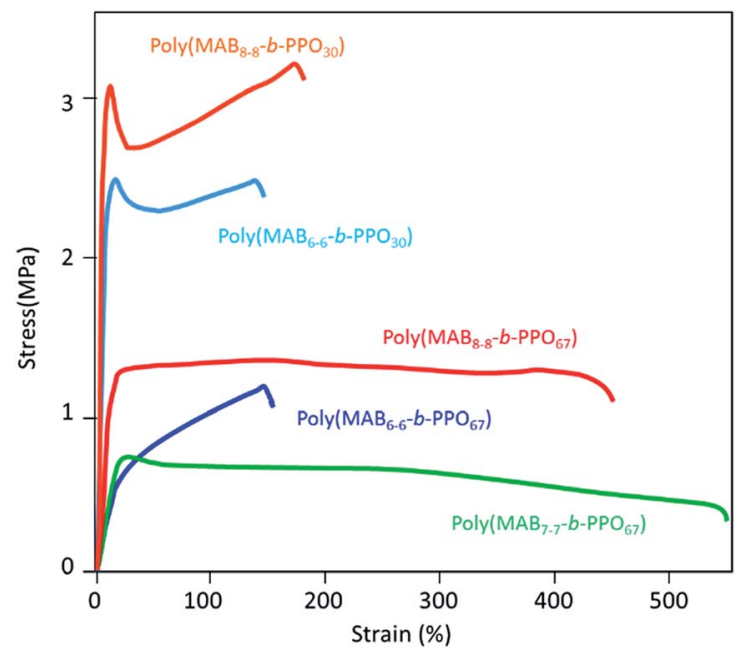

Fig. 11 Strain-stress curves of multiblock copolymers (poly $\left(\mathrm{MAB}_{x-x^{-}}\right.$ b- $\left.\mathrm{PPO}_{y}\right)$ ).

Table 2 Mechanical properties of poly $\left(\mathrm{MAB}_{x-x}-b-\mathrm{PPO}\right)$

\begin{tabular}{|c|c|c|c|c|}
\hline Polymer & $T_{\mathrm{M}}{ }^{a}(\mathrm{MPa})$ & $T_{\mathrm{S}}^{b}(\mathrm{MPa})$ & $E_{\mathrm{B}}^{c}(\%)$ & $f_{\mathrm{HS}}(\%)$ \\
\hline Poly $\left(\mathrm{MAB}_{6-6}-b-\mathrm{PPO}_{30}\right)$ & 28.0 & 2.2 & 150 & 48.8 \\
\hline Poly( $\left.\mathrm{MAB}_{6-6}-b-\mathrm{PPO}_{67}\right)$ & 3.3 & 1.7 & 155 & 30.7 \\
\hline Poly($\left(\mathrm{MAB}_{7-7}-b-\mathrm{PPO}_{67}\right)$ & 4.8 & 0.75 & 540 & 33.8 \\
\hline Poly( $\left.\mathrm{MAB}_{8-8}-b-\mathrm{PPO}_{30}\right)$ & 32.5 & 3.5 & 185 & 55.3 \\
\hline Poly(MAB $\left.{ }_{8-8}-b-\mathrm{PPO}_{67}\right)$ & 6.0 & 1.6 & 455 & 36.5 \\
\hline
\end{tabular}

${ }^{a}$ Young's modulus. ${ }^{b}$ Tensile strength. ${ }^{c}$ Elongation at break.

be critical to form clear phase segregation structure. This resulted in the mechanical properties of the films. Namely, the longer HS unit in the copolymer is the better for the mechanical properties. In other words, the mechanical properties can be slowly changed, and thus we have more opportunity to tune the properties.

Fig. 11 depicts the stress-strain curves of the block copolymer films, and the mechanical properties are summarized in Table 2. Polymer films having short SSs were hard, but they showed an adequate elongation at break $\left(E_{\mathrm{B}}\right)$ of over $150 \%$. In contrast, the films having long SSs showed much better ductility, and thus, the $E_{\mathrm{B}}$ values were over $500 \%$. The tensile modulus $\left(T_{\mathrm{M}}\right)$ of the films depended on the fraction and length of the HSs; $T_{\mathrm{M}}$ values were found to be in the following order: poly $\left(\mathrm{MAB}_{8-8}-b-\mathrm{PPO}_{30}\right)\left(f_{\mathrm{HS}}=55.3 \%\right)>\operatorname{poly}\left(\mathrm{MAB}_{6-6}-b-\mathrm{PPO}_{30}\right)\left(f_{\mathrm{HS}}\right.$ $=48.8 \%)>\operatorname{poly}\left(\mathrm{MAB}_{8-8}-b-\mathrm{PPO}_{67}\right)\left(f_{\mathrm{HS}}=36.5 \%\right)>\operatorname{poly}\left(\mathrm{MAB}_{7-7}-b-\right.$ $\left.\mathrm{PPO}_{67}\right)\left(f_{\mathrm{HS}}=33.8 \%\right)>\operatorname{poly}\left(\mathrm{MAB}_{6-6}-b-\mathrm{PPO}_{67}\right)\left(f_{\mathrm{HS}}=30.7 \%\right)$. The mechanical strength data in Table 2 are all superior to those of hyper-branched type poly $\left(\mathrm{MAB}_{x-x}-b-\mathrm{PPO}_{y}\right)$ in our previous report, ${ }^{55}$ so the packing of the HS molecules be favored in the linear polymer. The modulus against $f_{\mathrm{HS}}$ is plotted in Fig. 12 . The hardness of the film is related to the $f_{\mathrm{Hs}}$ value, but the slope of the fitted line seems different between $\mathrm{PPO}_{30^{-}}$and $\mathrm{PPO}_{67^{-}}$ based copolymers. And these plots are not on the same fitted line. As described in Introduction, the use of monodisperse $N$ -

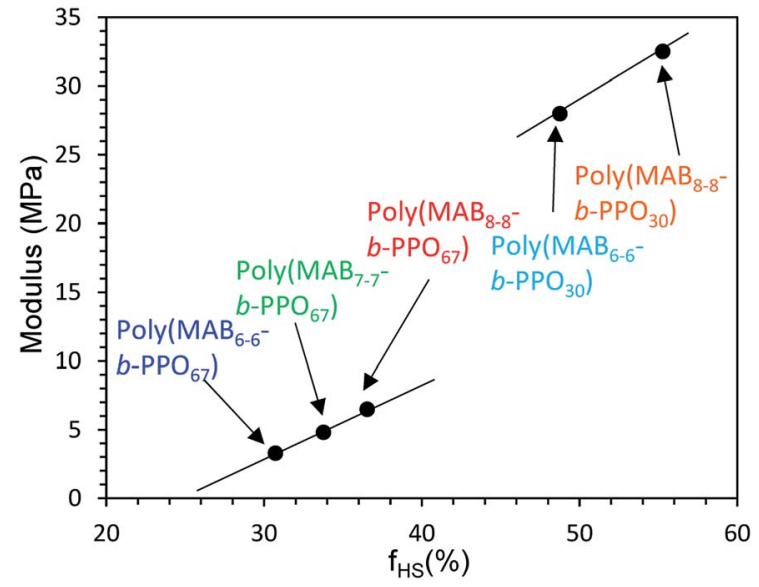

Fig. 12 Relationship between modulus and strain of poly $\left(\mathrm{MAB}_{x-x}-b-\right.$ PPOy).

methylated aromatic poly( $p$-benzamide) segment as a novel PEBA material could allow us a fine tuning of the film properties, the results in Fig. 12 supported this assumption. In addition, the $\mathrm{HS}$ of the poly $\left(\mathrm{MAB}_{x-x}-b-\mathrm{PPO}_{y}\right)$ shows an excellent thermal stability of $5 \%$ weight loss temperature in $\mathrm{N}_{2} T_{\mathrm{d} 5}=$ $408{ }^{\circ} \mathrm{C}$, while aliphatic amide, nylon 6 shows the value of at $320^{\circ} \mathrm{C}$. The ease of preparation and higher thermostability can be useful of the application of this monodisperse $N$-methylated aromatic poly( $p$-benzamide) compound.

\section{Experimental}

\section{Materials}

4-( $N$-Methylamino)benzoic acid (MBA) was purchased from Wako Pure Chemical Industries, Ltd., and purified by sublimation. Poly(propylene glycol) bis(2-aminopropyl ether)s $\left(\mathrm{PPO}_{y}\right)$ were purchased from Sigma-Aldrich Co. LLC., and the numberaverage molecular weight $\left(M_{\mathrm{n}}\right)$ and degree of polymerization $(y)$ were estimated by ${ }^{1} \mathrm{H}$ NMR measurement. Two samples of $\mathrm{PPO}_{y}$ $\left(M_{\mathrm{n}}=1875 \mathrm{~g} \mathrm{~mol}^{-1}, y=30\right.$ and $\left.M_{\mathrm{n}}=4025 \mathrm{~g} \mathrm{~mol}^{-1}, y=67\right)$ were used. $N$-Methylpyrrolidone (NMP) was dried over calcium hydride $\left(\mathrm{CaH}_{2}\right)$ and distilled under reduced pressure. Thionyl chloride was distilled prior to use. Diphenyl (2,3-dihydro-2thioxo-3-benzoxazolyl)phosphonate (DBOP) was prepared according to the literature. ${ }^{56}$ The other reagents and solvents were used without further purification.

\section{Synthesis of low molar mass distribution $4-(N$-methyl) benzamide molecules $\left(\mathrm{MAB}_{x-x}\right)$}

Typical procedure $\left(\mathbf{M A B}_{5-5}\right)$. Terephthalic acid chloride $(0.406 \mathrm{~g}, 2.00 \mathrm{mmol})$ and NMP $(2 \mathrm{~mL})$ were added to a $30 \mathrm{~mL}$ two-necked flask equipped with a three-way stopcock and a nitrogen inlet, at $20^{\circ} \mathrm{C}$. The building block, MAB $(0.604 \mathrm{~g}, 4.00$ mmol), was added to the mixture, and the reaction was performed at $20^{\circ} \mathrm{C}$ for $30 \mathrm{~min}$ to give the condensation product $\mathrm{MAB}_{1-1}$. Thionyl chloride $(0.604 \mathrm{~g}, 4.00 \mathrm{mmol})$ was then added and stirred for $30 \mathrm{~min}$ at that temperature (activation). Again, MBA ( $0.604 \mathrm{~g}, 4.00 \mathrm{mmol}$ ) was added to the mixture to perform 
the condensation reaction, resulting in the condensation product $\mathrm{MAB}_{2-2}$. This activation and condensation reaction process was repeated another three times, and the resulting solution was poured into distilled water to precipitate the product. The collected light brown powder was recrystallized with methanol/water mixed solvent and dried at $100{ }^{\circ} \mathrm{C}$ for $8 \mathrm{~h}$ to afford the title compound.

MAB $_{5-5}$. Yield: $1.24 \mathrm{~g}(82.8 \%) .{ }^{1} \mathrm{H}$ NMR $\left(\mathrm{CDCl}_{3}, 400 \mathrm{MHz}\right.$, ppm): $\delta$ 3.31-3.72 (m, 30H, -CH3), 6.71-7.36 (m, 40H, -ArH), $7.85(\mathrm{~m}, 4 \mathrm{H},-\mathrm{ArH}) .{ }^{13} \mathrm{C} \mathrm{NMR}\left(\mathrm{CDCl}_{3}, 100 \mathrm{MHz}, \mathrm{ppm}\right): \delta 35.5$, 120.5, 126.2, 127.5, 129.1, 130.3, 136.9, 141.6, 143.3, 163.7, 172.0. IR (KBr, cm $\left.{ }^{-1}\right): \nu 3466(\mathrm{COOH}), 3048(\mathrm{ArH}), 2938\left(\mathrm{CH}_{3}\right)$, $1650(\mathrm{C}=\mathrm{O}), 1602(\mathrm{C}=\mathrm{C}), 1354$ (amide $\mathrm{C}-\mathrm{N}), 1102\left(\mathrm{CH}_{3}-\mathrm{N}\right)$. Anal. calcd for $\left(\mathrm{C}_{88} \mathrm{H}_{76} \mathrm{~N}_{10} \mathrm{O}_{14}\right)$ : C, 70.58; H, 5.12; N, 9.35\%. Found: C, 67.71; H, 5.07; N, 8.95\%.

MAB $_{6-6}$. Yield: $82.5 \%$. ${ }^{1} \mathrm{H}$ NMR $\left(\mathrm{CDCl}_{3}, 400 \mathrm{MHz}, \mathrm{ppm}\right)$ :

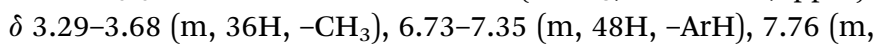
$4 \mathrm{H},-\mathrm{ArH}) .{ }^{13} \mathrm{C} \mathrm{NMR}\left(\mathrm{CDCl}_{3}, 100 \mathrm{MHz}, \mathrm{ppm}\right): \delta 34.7,120.3$, 126.0, 127.3, 128.6, 130.0, 137.3, 140.9, 142.8, 163.4, 172.0. IR $\left(\mathrm{KBr}, \mathrm{cm}^{-1}\right): \nu 3494(\mathrm{COOH}), 3051(\mathrm{ArH}), 2937\left(\mathrm{CH}_{3}\right), 1651(\mathrm{C}=$ O), $1603(\mathrm{C}=\mathrm{C}), 1356$ (amide $\mathrm{C}-\mathrm{N}), 1109\left(\mathrm{CH}_{3}-\mathrm{N}\right)$.

MAB $_{7-7}$. Yield: $81.1 \%$. ${ }^{1} \mathrm{H}$ NMR $\left(\mathrm{CDCl}_{3}, 400 \mathrm{MHz}, \mathrm{ppm}\right)$ : ס 3.31-3.72 (m, 42H, $\left.-\mathrm{CH}_{3}\right), 6.71-7.36(\mathrm{~m}, 56 \mathrm{H},-\mathrm{ArH}), 7.75(\mathrm{~m}$, $4 \mathrm{H},-\mathrm{ArH}) .{ }^{13} \mathrm{C} \mathrm{NMR}\left(\mathrm{CDCl}_{3}, 100 \mathrm{MHz}, \mathrm{ppm}\right): \delta$ 35.7, 120.5, 126.2, 127.3, 129.0, 130.1, 137.1, 141.6, 143.1, 163.8, 172.1. IR $(\mathrm{KBr}): \nu 3051(\mathrm{~N}-\mathrm{H}), 2923$ (aliphatic $\mathrm{C}-\mathrm{H}), 1645(\mathrm{C}=\mathrm{O}), 1368$ $(\mathrm{Ar}-\mathrm{N}), \quad 1175$ (amide $\mathrm{C}-\mathrm{N}) \quad \mathrm{cm}^{-1}$. Anal. calcd for $\left(\mathrm{C}_{120} \mathrm{H}_{104} \mathrm{~N}_{14} \mathrm{O}_{18}\right)$ : C, 70.99; H, 5.16; N, 9.66\%. Found: C, 68.51; $\mathrm{H}, 5.17$; N, 9.04\%.

MAB $_{8-8}$. Yield: $78.5 \%$. ${ }^{1} \mathrm{H}$ NMR $\left(\mathrm{CDCl}_{3}, 400 \mathrm{MHz}, \mathrm{ppm}\right)$ : $\delta 3.28-3.69\left(\mathrm{~m}, 48 \mathrm{H},-\mathrm{CH}_{3}\right), 6.70-7.40(\mathrm{~m}, 64 \mathrm{H},-\mathrm{ArH}), 7.87(\mathrm{~m}$, $4 \mathrm{H},-\mathrm{ArH}) .{ }^{13} \mathrm{C} \mathrm{NMR}\left(\mathrm{CDCl}_{3}, 100 \mathrm{MHz}, \mathrm{ppm}\right): \delta 35.9,120.5$, 126.2 , 126.7, 127.1, 129.2, 130.3, 136.8, 141.6, 142.8, 162.5, 171.8 .

MAB $_{9-9}$. Yield: $76.7 \% .{ }^{1} \mathrm{H}$ NMR $\left(\mathrm{CDCl}_{3}, 400 \mathrm{MHz}, \mathrm{ppm}\right)$ :

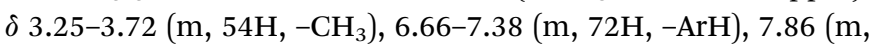
$4 \mathrm{H},-\mathrm{ArH}) .{ }^{13} \mathrm{C} \mathrm{NMR}\left(\mathrm{CDCl}_{3}, 100 \mathrm{MHz}, \mathrm{ppm}\right): \delta 35.7,121.5$, 126.5, 127.8, 132.4, 138.1, 143.6, 145.6, 163.8, 171.1, 175.4. IR $\left(\mathrm{KBr}, \mathrm{cm}^{-1}\right): \nu 3478(\mathrm{COOH}), 3053(\mathrm{ArH}), 2940\left(\mathrm{CH}_{3}\right), 1646(\mathrm{C}=$ O), $1602(\mathrm{C}=\mathrm{C}), 1353$ (amide $\mathrm{C}-\mathrm{N}), 1102\left(\mathrm{CH}_{3}-\mathrm{N}\right)$.

MAB $10-10$. Yield: $77.5 \% .{ }^{1} \mathrm{H}$ NMR $\left(\mathrm{CDCl}_{3}, 400 \mathrm{MHz}, \mathrm{ppm}\right)$ :

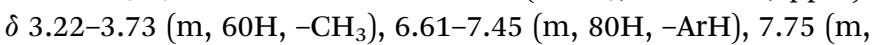
$4 \mathrm{H},-\mathrm{ArH}) .{ }^{13} \mathrm{C} \mathrm{NMR}\left(\mathrm{CDCl}_{3}, 100 \mathrm{MHz}, \mathrm{ppm}\right): \delta 34.7,120.3$, 127.2, 128.5, 130.1, 132.4, 136.0, 137.1, 141.6, 143.1, 163.8, 172.1, 175.5. IR (KBr, $\left.\mathrm{cm}^{-1}\right): \nu 3498(\mathrm{COOH}), 3052(\mathrm{ArH}), 2935$ $\left(\mathrm{CH}_{3}\right), 1647(\mathrm{C}=\mathrm{O}), 1602(\mathrm{C}=\mathrm{C}), 1351$ (amide $\left.\mathrm{C}-\mathrm{N}\right), 1102\left(\mathrm{CH}_{3}-\right.$ $\mathrm{N})$. Anal. calcd for $\left(\mathrm{C}_{168} \mathrm{H}_{146} \mathrm{~N}_{20} \mathrm{O}_{24}\right)$ : C, 71.32; H, 5.20; N, 9.90\%. Found: C, 69.51; H, 5.22; N, 9.36\%.

\section{Synthesis of broad molar mass distribution oligo[4-( $N$-methyl) benzamide] (bMAB $\left.{ }_{5-5}\right)$}

Terephthalic acid (0.166 g, $1.00 \mathrm{mmol})$ and MAB (1.510 g, 10.08 mmol) were dissolved with NMP (1 mL) in a $30 \mathrm{~mL}$ two-necked flask equipped with a three-way stopcock and a nitrogen inlet at $20{ }^{\circ} \mathrm{C}$. Thionyl chloride $(2.32 \mathrm{~g}, 4.04 \mathrm{mmol})$ was then added and stirred for $7 \mathrm{~h}$ at that temperature. The additional $2 \mathrm{~mL}$ NMP was added, and kept stirring for another $7 \mathrm{~h}$. The resulting solution was poured into distilled water to precipitate the product. The collected light brown powder was dried at $100{ }^{\circ} \mathrm{C}$ for $10 \mathrm{~h}$ to afford the title compound. Yield: $1.335 \mathrm{~g}(84.2 \%) .{ }^{1} \mathrm{H}$ NMR $\left(\mathrm{CDCl}_{3}, 400 \mathrm{MHz}, \mathrm{ppm}\right): \delta 3.31-3.72\left(\mathrm{~m}, 30 \mathrm{H},-\mathrm{CH}_{3}\right), 4.00-$ 4.90 (br, 9.2H, $\left.\operatorname{ArNH}\left(\mathrm{CH}_{3}\right)\right), 6.71-7.36(\mathrm{~m}, 40 \mathrm{H},-\mathrm{ArH}), 7.91(\mathrm{~m}$, $4 \mathrm{H},-\mathrm{ArH})$. 13C NMR $\left(\mathrm{CDCl}_{3}, 100 \mathrm{MHz}, \mathrm{ppm}\right): \delta 35.5,120.5$, 126.2, 127.5, 129.1, 130.3, 136.9, 141.6, 143.3, 163.7, 172.0. IR $\left(\mathrm{KBr}, \mathrm{cm}^{-1}\right): \nu 3466(\mathrm{COOH}), 3048(\mathrm{ArH}), 2938\left(\mathrm{CH}_{3}\right), 1650(\mathrm{C}=$ $\mathrm{O}), 1602(\mathrm{C}=\mathrm{C}), 1354$ (amide $\mathrm{C}-\mathrm{N}), 1102\left(\mathrm{CH}_{3}-\mathrm{N}\right)$. Anal. calcd for $\left(\mathrm{C}_{88} \mathrm{H}_{76} \mathrm{~N}_{10} \mathrm{O}_{14}\right)$ : C, 70.58; H, 5.12; N, 9.35\%. Found: C, 67.71; $\mathrm{H}, 5.07$; N, 8.95\%.

\section{Multiblock copolymerization of $\mathrm{MAB}_{x-x}$ with $\mathrm{PPO}_{y}$ $\left(\right.$ poly $\left(\mathbf{M A B}_{x-\boldsymbol{x}}-\boldsymbol{b}-\mathbf{P P O}_{\boldsymbol{y}}\right)$ )}

The typical procedure for poly $\left(\mathrm{MAB}_{5-5}-b-\mathrm{PPO}_{30}\right)$ was as follows. $\mathrm{MAB}_{5-5}(0.375 \mathrm{~g}, 0.250 \mathrm{mmol}), \mathrm{PPO}_{30}(0.469 \mathrm{~g}, 0.250 \mathrm{mmol})$, triethylamine $(0.0600 \mathrm{~g}, 0.600 \mathrm{mmol})$, and NMP $(2 \mathrm{~mL})$ were added to a $30 \mathrm{~mL}$ two-necked flask equipped with a three-way stopcock and a nitrogen inlet, at $20{ }^{\circ} \mathrm{C}$. DBOP (0.230 g, 0.600 $\mathrm{mmol}$ ) was added to initiate the polymerization. After stirring at $20{ }^{\circ} \mathrm{C}$ for $6 \mathrm{~h}$, the solution was poured into $3 \mathrm{wt} \% \mathrm{NaHCO}_{3}$ (aq.). The precipitate was collected and dried under vacuum at $100{ }^{\circ} \mathrm{C}$ for $8 \mathrm{~h}$ to afford a viscous brown polymeric compound. Yield: 84.2\%. ${ }^{1} \mathrm{H}$ NMR $\left(\mathrm{CDCl}_{3}, 400 \mathrm{MHz}, \mathrm{ppm}\right): \delta 1.12-1.26\left(\mathrm{~m},-\mathrm{CH}_{3}\right)$, $1.27\left(\mathrm{t},-\mathrm{CH}_{3}\right), 3.35-3.72\left(\mathrm{~m},-\mathrm{CH}_{2},-\mathrm{CH}_{3}\right), 6.75-7.21(\mathrm{~m},-\mathrm{ArH})$. ${ }^{13} \mathrm{C} \mathrm{NMR}\left(\mathrm{CDCl}_{3}, 100 \mathrm{MHz}, \mathrm{ppm}\right): \delta 17.6,73.0,73.5,75.4,120.4$, 123.6, 126.1, 129.3, 129.9. IR (KBr, $\left.\mathrm{cm}^{-1}\right): \nu 3051(\mathrm{~N}-\mathrm{H}), 2923$ (aliphatic C-H), $1645(\mathrm{C}=\mathrm{O}), 1368(\mathrm{Ar}-\mathrm{N}), 1175\left(\mathrm{CH}_{3}-\mathrm{N}\right)$.

\section{Measurements}

Fourier transform IR spectra were measured with a Jasco IR5500 (Jasco Co., Ltd.) by transmittance absorption spectroscopy (KBr tablet method). The molecular mass of polymers [number- and weight-average $\left(M_{\mathrm{n}}\right.$ and $\left.M_{\mathrm{w}}\right)$ ] was determined with a Tosoh HLC-8120 GPC using a consecutive polystyrene gel column (TSK-GEL GMHHR-M and GMHHR-N) at $40{ }^{\circ} \mathrm{C}$, eluted with NMP containing $0.01 \mathrm{~mol} \mathrm{~L}^{-1} \mathrm{LiBr}$ at a flow rate of $1.0 \mathrm{~mL} \mathrm{~min}^{-1}$. Nuclear magnetic resonance (NMR) was performed on a Bruker AC-400P spectrometer at $400 \mathrm{MHz}$ for ${ }^{1} \mathrm{H}$ and $100 \mathrm{MHz}$ for ${ }^{13} \mathrm{C}$ measurements. Deuterated chloroform $\left(\mathrm{CDCl}_{3}\right)$ was used as a solvent with tetramethylsilane as an internal reference. Thermal analyses were performed on a Seiko thermal analyzer (SCC 5200 system) at a heating rate of $10^{\circ} \mathrm{C} \mathrm{min}^{-1}$ for thermogravimetric analysis (TGA by TG/DTA 320) under air or nitrogen. Differential scanning calorimetry (DSC) was performed on a Shimadzu DSC-60 at a heating rate of $20^{\circ} \mathrm{C} \min ^{-1}$ under nitrogen. Dynamic mechanical analysis (DMA) was performed on a Shimadzu DMS-210 at a heating rate of $20^{\circ} \mathrm{C} \mathrm{min}^{-1}$ under nitrogen. Polymer films were cut into sizes of $20 \times 9 \times 0.12 \mathrm{~mm}^{3}$, and a load was applied to the films with a strain amplitude of $5 \mu \mathrm{m}$ and a frequency of $1 \mathrm{~Hz}$. The modes of several polymers in the crystalline phase were examined by wide-angle X-ray powder diffraction (WAXD) measurements using a Rigaku R-axis Rapid diffractometer equipped with a graphite monochromator, with $\mathrm{CuK} \alpha$ 
radiation at $45 \mathrm{kV}$ and $200 \mathrm{~mA}$. Tapping mode atomic force microscopy (AFM) measurements were performed with a NanoNavi S-image SPM system (Hitachi High-Tech Sci. Co., Tokyo, Japan) using a cantilever with a force constant of approximately $15 \mathrm{~N} \mathrm{~m}^{-1}$ and a resonance frequency of 120 $\mathrm{kHz}$. The scan size and a tip velocity of the AFM measurements are $10 \times 10 \mu^{2}$ and $200 \mathrm{~nm} \mathrm{~s}^{-1}$, respectively. Matrix-assisted laser desorption/ionization time-of-flight mass spectra (MALDI-TOF MS) were recorded on an AXIMA Confidence (SHIMADZU Corp., Kyoto, Japan). Dithranol was used as the matrix.

\section{Conclusions}

In this study, we prepared $N$-methyl benzamide-based monodisperse molecules (repeat number: $5-10 \times 2) \mathrm{MAB}_{x-x}$ for copolymerization with $\mathrm{PPO}_{y}$, characterized the structures, and evaluated the properties. The $\mathrm{MAB}_{x-x}$ molecules prepared by an authentic step-wise condensation reaction, using the reliable dendrimer synthetic method, exhibited quite narrow molar-mass distribution below 1.04 and the $T_{\mathrm{g}}$ was $170-178{ }^{\circ} \mathrm{C}$, depending on the length of the repeating unit. These rigid-rod molecules were successfully copolymerized with $\mathrm{PPO}_{y}$, giving the copolymer poly $\left(\mathrm{MAB}_{x-x}-b-\mathrm{PPO}_{y}\right)$ in good yield with $M_{\mathrm{n}}$ up to $12500 \mathrm{~g} \mathrm{~mol}^{-1}\left(M_{\mathrm{w}} / M_{\mathrm{n}}=1.6\right)$. As a control, the polydisperse HS $\left(b \mathrm{MAB}_{5-5}, M_{\mathrm{n}} 1470, M_{\mathrm{w}} / M_{\mathrm{n}}=1.45\right)$ was prepared, and copolymerized with PPO as well to form poly $\left(b \mathrm{MAB}_{5-5}-b\right.$ $\left.\mathrm{PPO}_{67}\right)\left(M_{\mathrm{n}} 9400 \mathrm{~g} \mathrm{~mol}^{-1}, M_{\mathrm{w}} / M_{\mathrm{n}}=1.8\right)$. Even though these finally obtained block copolymers have similar $M_{\mathrm{n}}$ and $M_{\mathrm{w}} / M_{\mathrm{n}}$ values, the initial storage modulus $E^{\prime}$, the peak intensity of $\tan \delta$ at $-50.7^{\circ} \mathrm{C}$, the $\tan \delta$ peak at $47.9^{\circ} \mathrm{C}$, and the appearance showed large differences. Thus, for the formation of the phasesegregated structure with non-hydrogen-bondable block copolymer system, the use of the monodisperse HS block is essential. The copolymers using monodisperse HS blocks showed a single $T_{\mathrm{g}}$ at $-60{ }^{\circ} \mathrm{C}$, assignable to the pure PPO domain by DSC. DMA analysis of the copolymer films clearly showed two $T_{\mathrm{g}}$ values at -60 and above $60{ }^{\circ} \mathrm{C}$, indicating the phase segregation of the copolymers. The mechanical properties of the copolymer films were mainly dependent on the fraction of the hard segment, and the tensile modulus and elongation at break varied from 3.3 to $28.0 \mathrm{MPa}$ and 150 to $540 \%$, respectively.

\section{Acknowledgements}

This work was financially supported by the Grant Co-funded by 3NUNT (National Universities of Northern Tohoku), Japan, and by the Iwate University Support Fund for Focused Research and formation of the Centre of Excellence, 2013, and CSTI, SIP (Research and development of innovative manufacture using molecular adhesion technology). We also thank Prof. Hideo Sawada (Hirosaki University) for their valuable discussion on this research. The authors thank Ms Shiduko Nakajo for MALDI-TOF MS measurement.

\section{Notes and references}

1 A. Asatekin, S. Kang, M. Elimelech and A. M. Mayes, J. Membr. Sci., 2007, 298, 136.

2 S. Y. Yang, I. Ryu, H. Y. Kim, J. K. Kim, S. K. Jang and T. P. Russell, Adv. Mater., 2006, 18, 709-712.

3 S. Y. Yang, J. Park, J. Yoon, M. Ree, S. K. Jang and J. K. Kim, Adv. Funct. Mater., 2008, 18, 1371-1377.

4 W. A. Phillip, M. Amendt, B. O'neill, L. Chen, M. A. Hillmyer and E. L. Cussler, ACS Appl. Mater. Interfaces, 2009, 1, 472-480.

5 E. E. Nuxoll, M. A. Hillmyer, R. Wang, C. Leighton and R. A. Siegel, ACS Appl. Mater. Interfaces, 2009, 1, 888-893.

6 K. Peinemann, V. Abetz and P. F. W. Simon, Nat. Mater., 2007, 6, 992-996.

7 H. Uehara, M. Kakiage, M. Sekiya, D. Sakuma, T. Yamonobe, N. Takano, A. Barraud, E. Meurville and P. Ryser, ACS Nano, 2009, 3, 924-932.

8 A. Urbas, R. Sharp, Y. Fink, E. L. Thomas, M. Xenidou and L. J. Fetters, Adv. Mater., 2000, 12, 812-814.

9 M. R. Bockstaller, Y. Lapetnikov, S. Margel and E. L. Thomas, J. Am. Chem. Soc., 2003, 125, 5276-5277.

10 J. Yoon, R. T. Mathers, G. W. Coates and E. L. Thomas, Macromolecules, 2006, 39, 1913-1919.

11 C. Osuji, C.-Y. Chao, I. Bita, C. K. Ober and E. L. Thomas, Adv. Funct. Mater., 2002, 12, 753-758.

12 J. Yoon, W. Lee and E. L. Thomas, Nano Lett., 2006, 6, 22112214.

13 R. A. Segalman, H. Yokoyama and E. J. Kramer, Adv. Mater., 2001, 13, 1152-1155.

14 D. Sundrani, S. B. Darling and S. J. Sibener, Nano Lett., 2004, 4, 273-276.

15 T. L. Morkved, M. Lu, A. M. Urbas, E. E. Ehrichs, H. M. Jaeger, P. Mansky and T. P. Russell, Science, 1996, 273, 931-933.

16 C. D. Rosa, C. Park, E. L. Thomas and B. Lotz, Nature, 2000, 405, 433-436.

17 K. Kataoka, A. Harada and Y. Nagasaki, Adv. Drug Delivery Rev., 2001, 47, 113-131.

18 A. Rösler, G. W. M. Vandermeulen and H.-A. Klok, Adv. Drug Delivery Rev., 2012, 64, 270-279.

19 R. J. Gaymans, Prog. Polym. Sci., 2011, 36, 713-748.

20 G. Rabani, G. M. Rosair and A. Kraft, J. Polym. Sci., Part A: Polym. Chem., 2004, 42, 1449-1460.

21 M. Peyravi, A. A. Babaluo, M. A. Ardestani, M. K. R. Aghjeh, S. R. Pishghadam and P. Hadi, J. Appl. Polym. Sci., 2010, 118, 1211-1218.

22 J. F. Feller and Y. Grohens, Sens. Actuators, B, 2004, 97, 231242.

23 C. Yi. Z. Peng, H. Wang, M. Li and C. Wang, Polym. Int., 2011, 60, 1728-1736.

24 I. K. Yang and P. H. Tsai, J. Polym. Sci., Part B: Polym. Phys., 2005, 43, 2557-2567.

25 M. Van der Schuur, J. D. Boer and R. Gaymans, Polymer, 2005, 46, 9243-9256.

26 C. Y. Yeong and H. J. Won, J. Appl. Polym. Sci., 1994, 54, 585591. 
27 C. Y. Yeong and H. J. Won, J. Appl. Polym. Sci., 1995, 56, 895904.

28 L. Liu, A. Chakma and X. Feng, J. Membr. Sci., 2004, 235, 4352.

29 L. Liu, A. Chakma and X. Feng, Chem. Eng. Sci., 2006, 61, 6142-6153.

30 A. Gugliuzza and E. Drioli, Polymer, 2003, 44, 2149-2157.

31 S. Sridhar, R. Suryamurali, B. Smitha and T. M. Aminabhavi, Colloids Surf., A, 2007, 297, 267-274.

32 L. J. Harrell, Macromolecules, 1969, 2, 607-612.

33 G. L. Wilkes, S. L. Samuels and R. Crystal, J. Macromol. Sci., Part B: Phys., 1974, 10, 203-229.

34 J. A. Miller, S. B. Lin, K. K. S. Hwang, K. S. Wu, P. E. Gibson and S. L. Cooper, Macromolecules, 1985, 18, 32-44.

35 R. J. Gaymans and J. L. de Haan, Polymer, 1993, 34, 43604364.

36 K. Bouma, G. A. Wester and R. J. Gaymans, Polym. Sci. Eng, 2001, 41, 1173-1180.

37 G. Perego, M. Cesari, G. Della Fortuna and J. St, Appl. Polym. Sci., 1984, 29, 1141-1155.

38 J. M. Van der Schuur and R. J. Gaymans, J. Polym. Sci., Part A: Polym. Chem., 2006, 44, 4769-4781.

39 D. Husken, T. Visser, M. Wessling and R. J. Gaymans, J. Membr. Sci., 2010, 346, 194-201.

40 P. W. Morgan, Macromolecules, 1977, 10, 1381-1390.

41 S. L. Kwolek, P. W. Morgan, J. R. Schaefgen and L. W. Gulrich, Macromolecules, 1977, 10, 1390-1396.

42 T. I. Bair, P. W. Morgan and F. L. Killian, Macromolecules, 1977, 10, 1396-1400.

43 J. P. Hummel and P. J. Flory, Macromolecules, 1980, 13, 479484.
44 A. Itai, Y. Toriumi, N. Tomioka, H. Kagechika, I. Azumaya and K. Shudo, Tetrahedron Lett., 1989, 30, 6177-6180.

45 I. Azumaya, H. Kagechika, Y. Fujiwara, M. Itoh, K. Yamaguchi and K. Shudo, J. Am. Chem. Soc., 1991, 113, 2833-2838.

46 K. Yamaguchi, G. Matsumura, H. Kagechika, I. Azumaya, Y. Ito, A. Itai and K. Shudo, J. Am. Chem. Soc., 1991, 113, 5474-5475.

47 A. Itai, Y. Toriumi, S. Saito, H. Kagechika and K. Shudo, J. Am. Chem. Soc., 1992, 114, 10649-10650.

48 I. Azumaya, I. Yamaguchi, Y. Okamoto, H. Kagechika and K. Shudo, J. Am. Chem. Soc., 1995, 117, 9083-9084.

49 A. Tanatani, A. Yokoyama, I. Azumaya, Y. Takakura, C. Mitsui, S. Motoo, M. Uchiyama, A. Muranaka, N. Kobayashi and T. Yokozawa, J. Am. Chem. Soc., 2005, 127, 8553-8561.

50 Y. Shibasaki, Y. Abe, N. Sato, A. Fujimori and Y. Oishi, Polym. J., 2010, 42, 72-80.

51 S. Chiba, S. Arai, Y. Kaneko, M. Taguchi, Y. Shibasaki and A. Fujimori, Trans. Mater. Res. Soc. Jpn., 2012, 37, 283-286.

52 A. Fujimori, Y. Kaneko, T. Kikkawa, S. Chiba and Y. Shibasaki, J. Colloid Interface Sci., 2014, 418, 338-349.

53 A. Fujimori, S. Miura, T. Kikkawa and Y. Shibasaki, J. Polym. Sci., Part B: Polym. Phys., 2014, 418, 338-349.

54 I. Washio, Y. Shibasaki and M. Ueda, Macromolecules, 2005, 38, 2237-2246.

55 S. Masukawa, T. Kikkawa, A. Fujimori, Y. Oishi and Y. Shibasaki, Chem. Lett., 2015, 44, 536-538.

56 M. Ueda, M. Katayama, T. Morosumi and R. Sato, Polym. J., 1991, 23, 167-176. 